\title{
Sendai Water Pipeline Response to the 2011 Tohoku
}

\section{Earthquake}

\author{
Kazue Wakamatsu ${ }^{1}$, Shigeru Nagata ${ }^{2}$, Yoshihisa Maruyama ${ }^{3}$ and Kyoko Ozawa ${ }^{4}$ \\ 1. Department of Civil Engineering, Kanto Gakuin University, Yokohama 236-8501, Japan \\ 2. Disaster Prevention and Wind Engineering Group, Kajima Technical Research Institute, Kajima Corporation, Tokyo 182-0036, \\ Japan \\ 3. School of Engineering, Chiba University, Chiba 263-8522, Japan \\ 4. Department of Integrated Research on Disaster Prevention, National Research Institute for Earth Science and Disaster
}

Prevention, Tsukuba 305-0006, Japan

\begin{abstract}
Damage caused by the 2011 Tohoku Earthquake $\left(M_{w} 9.0\right)$ to transmission and distribution pipelines in Sendai City is summarized. The locations of the pipeline repairs are discussed relative to earthquake intensity, geomorphologic conditions and landform change in the developed areas of hilly land. Repair rate (repairs $/ \mathrm{km}$ ) is summarized according to pipe material and presence or absence of artificial landform change. The following findings were obtained: (1) More than $80 \%$ of the repairs took place in pipelines installed in higher lands such as hill and terrace areas consisting of hard soils; (2) Nearly all the pipe repair locations in hill areas are where landform change was made through land development for residential purposes over the past several decades; (3) The aforementioned repair rate was more than 3.6 times than that of other lowland areas where no landform change occurred. The heaviest concentrations of pipe repairs of vinyl chloride pipes and ductile iron pipes were observed within the boundary area between cutting and filling, having a thickness between $-2.5 \mathrm{~m}$ and $2.5 \mathrm{~m}$. Approximately $78 \%$ of the all pipe repairs occurred outside of areas where severe ground failures took place. A mechanism of pipe damage in the areas free of severe ground failure was discussed.
\end{abstract}

Key words: Water pipeline damage, the 2011 Tohoku Japan Earthquake, developed land, landform change, landslide.

\section{Introduction}

Sendai City is the most densely inhabited city in the Tohoku Region, the northern part of Japan's main island-Honshu, which was severely affected by the $M_{w}$ 9.0 Tohoku Earthquake of March 11, 2011 (officially named the 2011 off the Pacific Coast of Tohoku Earthquake by the Japanese Meteorological Agency). A 4,458-km water supply network in the city suffered extensive damage, with 1,064 locations seriously affected, resulting in cutoffs of water supply to approximately 230,000 households just after the earthquake. The damage to the water supply network included 437 transmission and distribution pipes, 522 water supply pipes and 105 pieces of auxiliary

Corresponding author: Kazue Wakamatsu, professor, research field: geotechnical earthquake engineering. equipment, i.e., air valves, hydrants, pressure reducing valves, etc.

Buried pipelines including water pipeline networks have been severely damaged during past major earthquakes in urban areas. Main cause of damage was liquefaction-induced ground deformation in artificial fills and/or flood plains of rivers, except in some cases caused by earthquake ground shaking and surface faulting [1-12].

However, water pipelines in Sendai during the 2011 Tohoku Earthquake, most of the damaged pipelines were found to be located above low-lying land consisting of soft soil, in hilly residential land. There is no precedent for so many pipelines being damaged in hilly land in Japan, and possibly any other country in the world either, with only exception in the same 
area, Sendai, during the 1978 Miyagiken-oki Earthquake [2]. In order to help preparation for future earthquakes, it is important to analyze the conditions at the damaged sites in the hilly land, especially the effects of artificial landform changes and their relation to occurrences of ground failures, because there are many of these types of residential land areas in Tokyo and its suburbs, as well as other metropolitan areas in Japan such as Nagoya and Osaka.

In this study, damage caused by the 2011 Tohoku Earthquake $\left(M_{w} 9.0\right)$ to transmission and distribution pipelines in Sendai City is summarized. The effects of landform on pipeline damage are analyzed to find out the cause of damage in hilly land, focusing artificial landform changes by development.

\section{Water Pipeline Response to the 2011 Tohoku Earthquake}

The City of Sendai, with a population over one million people and with an area of approximately $788 \mathrm{~km}^{2}$, is the biggest city in the Tohoku Region of Japan. About $66 \%$ of the total area of the city is land covered with forests and farmland, and only $16 \%$ of the area is used as residential land [13].

On March 11, 2011, at 2:46 p.m. local time, a $M_{w} 9.0$ earthquake struck along the subduction zone interface plate boundary between the Pacific and North American Plates. The earthquake was immediately followed by a large tsunami that inflicted widespread damage on eastern Japan's modern urban infrastructure, extending from northern Tohoku to the southern Kanto Region, an area that includes Sendai.

Recorded horizontal ground motion accelerations ranged from 254 to $1,869 \mathrm{~cm} / \mathrm{s}^{2}$ and velocities ranged from 31 to $145 \mathrm{~cm} / \mathrm{s}$ with JMA (Japan Meteorological Agency) intensities reaching 5 minor to 6 minor over large populated areas in Sendai $[14,15]$. Water supply to approximately 230,000 households was suspended (affecting a population of 500,000 with a water outage rate of $50 \%$ ) in Sendai; Eighteen days were required to restore water to all habitable service areas with the exception of tsunami affected and severe ground failure affected areas. This is a relatively short recovery period for an earthquake affected area [16].

The Sendai water system consists of eight water treatment plants and 14 water distribution plants, two pumping stations, and a 4458-km water distribution network. Although there was considerable damage to drainage facilities and civil engineering facilities, such as retaining walls and slopes in the yards, there was little functional damage at two water distribution plants [16].

In contrast, there was significant damage to water distribution pipelines. The $4458-\mathrm{km}$ water pipeline network in the city suffered extensive damage, with 1,064 locations seriously affected; The damage to the pipeline network includes 437 transmission and distribution pipes (Fig. 1), 522 water supply pipes, and 105 pieces of auxiliary equipment. Table 1 presents a summary of damage to transmission and distribution pipes, water supply pipes and auxiliary equipment, showing that approximately $90 \%$ of the water transmission and distribution pipe repairs were in pipelines made of VP and DIP, and having diameters less than $150 \mathrm{~mm}$. Furthermore, approximately

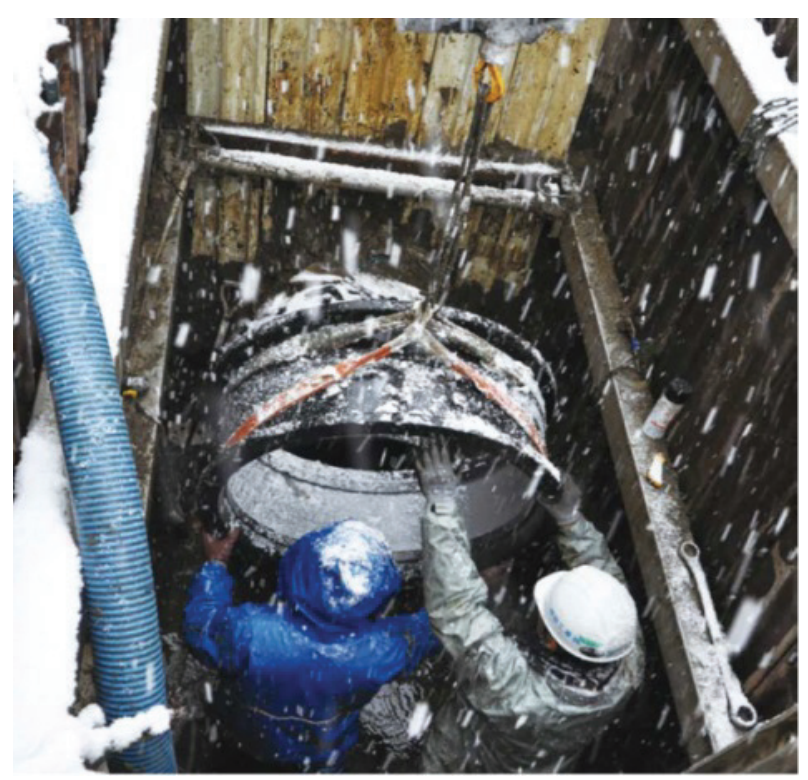

Fig. 1 Repair of water distribution pipe with a diameter of $800 \mathrm{~mm}[16]$. 
Table 1 Summary of water pipeline repairs and repair rate for the March 11, 2011 earthquake [16].

\begin{tabular}{|c|c|c|c|c|c|c|c|c|c|c|c|}
\hline & \multirow{2}{*}{ Diameter (mm) } & \multicolumn{7}{|c|}{ Pipe material and number of repairs } & \multirow{2}{*}{-Total } & \multirow{2}{*}{ Length (km) } & \multirow{2}{*}{ Repairs/km } \\
\hline & & CIP & DIP & $\mathrm{SP} / \mathrm{SU}$ & $\mathrm{VP}$ & LP & PP & GP & & & \\
\hline \multirow{6}{*}{$\begin{array}{l}\text { Water } \\
\text { transmission and } \\
\text { water distribution } \\
\text { pipes }\end{array}$} & 75 & 0 & 0 & 3 & 147 & 2 & 3 & 6 & 161 & 695.6 & 0.23 \\
\hline & 75 & 0 & 17 & 1 & 77 & - & - & - & 95 & 439.1 & 0.22 \\
\hline & $100 \sim 150$ & 0 & 74 & 6 & 73 & - & - & - & 153 & $2,236.4$ & 0.07 \\
\hline & $200 \sim 450$ & 0 & 23 & 1 & - & - & - & - & 24 & 861.6 & 0.03 \\
\hline & 500 & 0 & 3 & 1 & - & - & - & - & 4 & 225.5 & 0.02 \\
\hline & Subtotal & 0 & 117 & 12 & 297 & 2 & 3 & 6 & 437 & $4,458.0$ & 0.09 \\
\hline \multirow{4}{*}{$\begin{array}{l}\text { Water supply } \\
\text { pipes }\end{array}$} & 75 & 0 & 0 & 11 & 113 & 249 & 97 & 45 & 515 & 164.57 & 3.13 \\
\hline & 75 & 0 & 1 & 0 & 5 & 0 & 0 & 0 & 6 & 6.70 & 0.90 \\
\hline & $100 \sim 150$ & 0 & 0 & 0 & 1 & 0 & & 0 & 1 & 4.54 & 0.22 \\
\hline & Subtotal & 0 & 1 & 0 & 119 & 249 & 97 & 45 & 522 & 175.81 & 2.97 \\
\hline \multirow{6}{*}{$\begin{array}{l}\text { Auxiliary } \\
\text { equipment }\end{array}$} & Fire hydrant & 0 & 4 & 0 & 3 & 0 & 0 & 0 & 7 & & \\
\hline & Air valve & 0 & 38 & 16 & 2 & 0 & 0 & 0 & 56 & & \\
\hline & Sluice valve & 0 & 6 & 2 & 11 & 0 & 0 & 0 & 19 & & \\
\hline & Diversion valve & 0 & 12 & 0 & 10 & 0 & 0 & 0 & 22 & & \\
\hline & Water shutoff valve & 0 & 0 & 0 & 1 & 0 & 0 & 0 & 1 & & \\
\hline & Subtotal & 0 & 60 & 18 & 27 & 0 & 0 & 0 & 105 & & \\
\hline
\end{tabular}

CIP (cast iron pipe); DIP (ductile cast iron pipe); SP (steel pipe); SU (stainless steel pipe); VP (vinyl chloride pipe); LP (lead pipe); PP (Polyethylene pipe); GP(galvanized iron plating pipe).

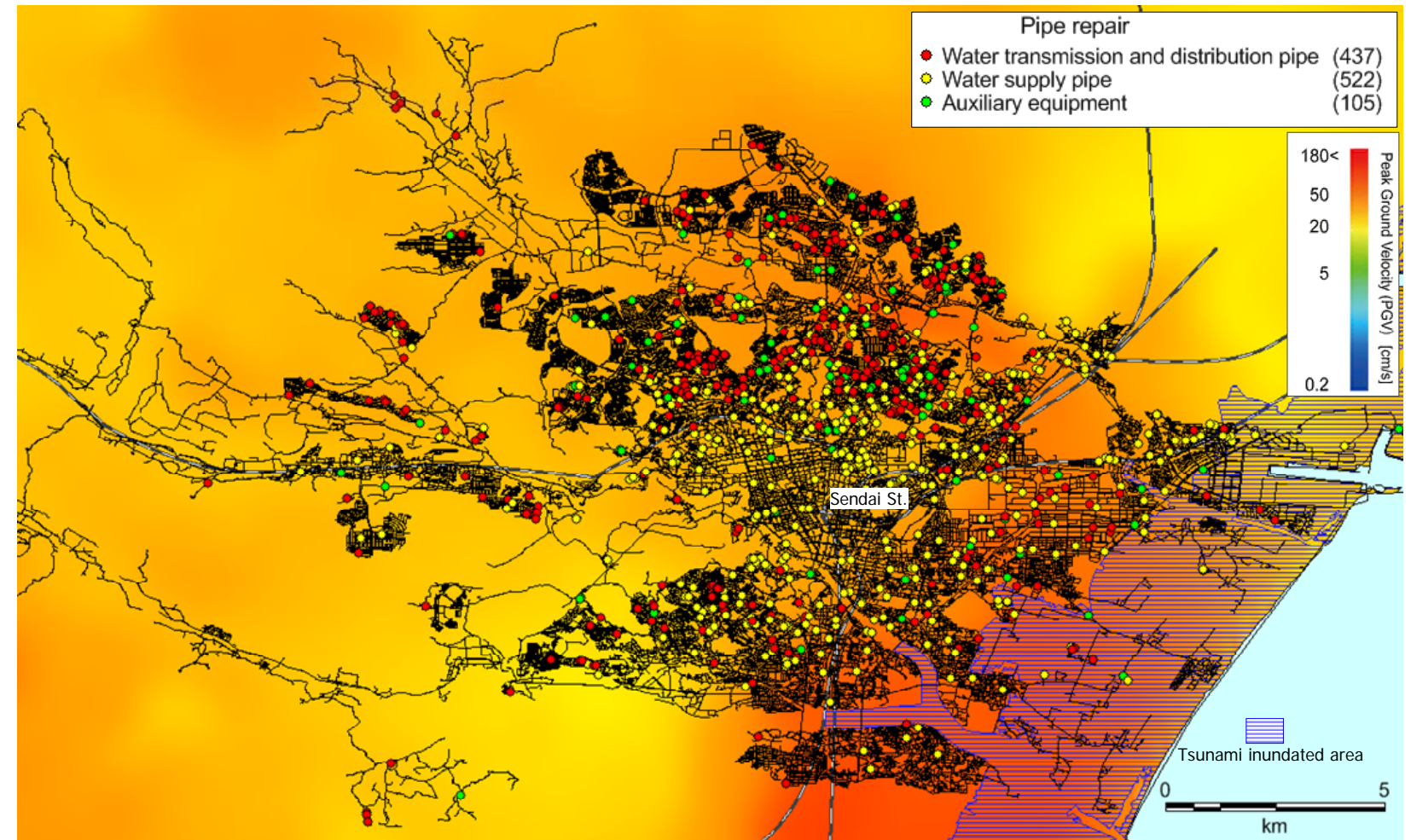

Fig. 2 Map of water transmission and distribution network (black lines) and repair locations in Sendai City during the March 11, 2011 earthquake superimposed on areas of tsunami inundation [17] and the estimated PGV distribution [18].

$99 \%$ of the water supply pipe repairs were in pipelines made of VP, LP, PP, and GP, having diameters less than $75 \mathrm{~mm}$.
Fig. 2 shows a map of the water transmission and distribution system including repair locations in Sendai City during the 2011 earthquake superimposed 
Table 2 Summary of water pipe repairs and repair rate by material for the March 11, 2011 earthquake [16].

\begin{tabular}{llll}
\hline Material & N. of repairs & Pipe length $(\mathrm{km})$ & Repairs $/ \mathrm{km}$ \\
\hline Cast iron (CIP) & 0 & 14.4 & 0 \\
Ductile cast iron (DIP)* $_{\text {Steel/Stainless steel }}$ & 117 & $2,723.1$ & 0.04 \\
Vinyl chloride (VP) & 12 & 137.3 & 0.09 \\
Lead (LP) & 297 & $1,514.5$ & 0.20 \\
Polyethylene (PP) & 2 & 3.4 & 0.59 \\
Galvanized iron plating (GP) & 3 & 52.7 & 0.06 \\
Total & 6 & 4.9 & 1.22 \\
\hline
\end{tabular}

*No damage was observed in ductile cast iron pipe connected with earthquake proof joints.

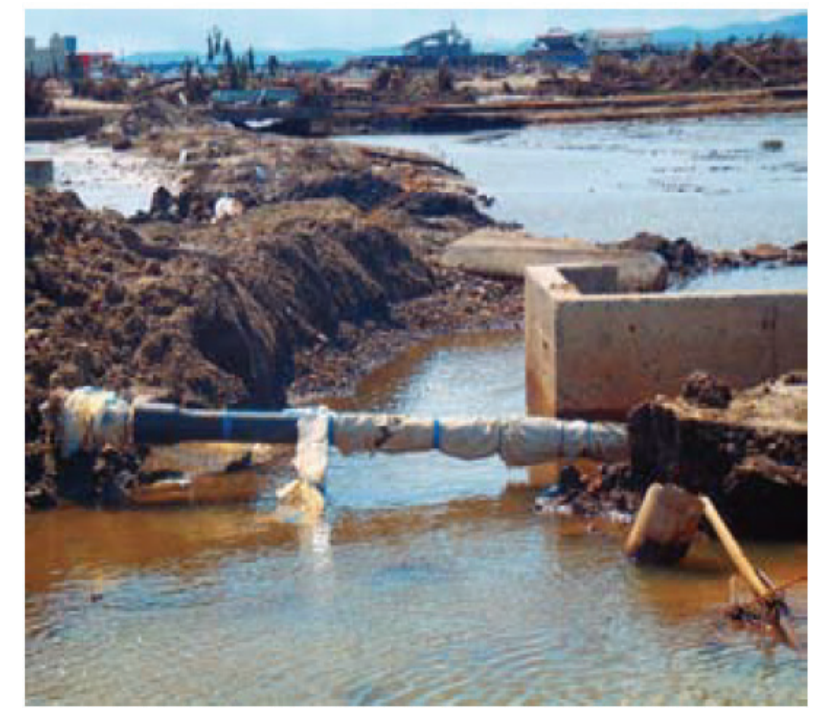

Fig. $3150 \mathrm{~mm}$-diameter DIP pipe with earthquake proof joints that survived the tsunami [16].

on areas of tsunami inundation [17] and the distribution of PGV (peak ground velocity) with a 250-m spatial resolution for the main event of the earthquake [18]. The PGV distribution was estimated by means of a spatial interpolation procedure, using the strong ground observation records [19]. It can be seen in Fig. 2 that the highest concentrations of damage were in the inland areas of the city where the PGVs are substantially lower than those of the coastal areas or outside tsunami inundated areas.

Table 2 displays the number of repairs, pipe length, and repair rate (repairs $/ \mathrm{km}$ ) in the Sendai water distribution network differentiated by pipe material.

The repair rate for GP was the highest among all the materials followed by LP, whereas no damage was found in CIP. The repair rate for DIP was fairly low, even with the longest pipe length of 2,723.1 km, corresponding to $61 \%$ of the total length of the water pipes. In addition, no damage was found in DIP with earthquake proof joints (Fig. 3).

\section{Relationship between Locations of Pipe Repairs and Geomorphologic Conditions}

First, the distribution of pipe repairs was superimposed on geomorphological classification map to understand the ground conditions of damaged sites. Fig. 4 shows the locations of pipe repairs and the water distribution network superimposed on the 7.5-sec JEGM (Japan Engineering Geomorphologic Classification Map), which is a nationwide site condition map based on the geomorphologic classification for various kinds of hazard mapping [20]. The damage to pipes was spread across hills (moss green), gravelly terraces (orange) and lowlands such as deltas and coastal lowlands (sky blue), alluvial fans (yellow-green), and back marsh (green).

The pie chart of Fig. 5 shows percentages of pipe repairs according to geomorphologic land classification, in which "other lowlands" include alluvial fans, natural levees, back marshes, and delta and coastal lowlands. Fig. 5 indicates that $69 \%$ and $12 \%$ of the pipe repairs took place in pipelines installed in hill and terrace areas, respectively. This implies that most of the damaged pipelines were located not on low-lying land consisting of soft soils, but on higher land consisting of hard soils. 


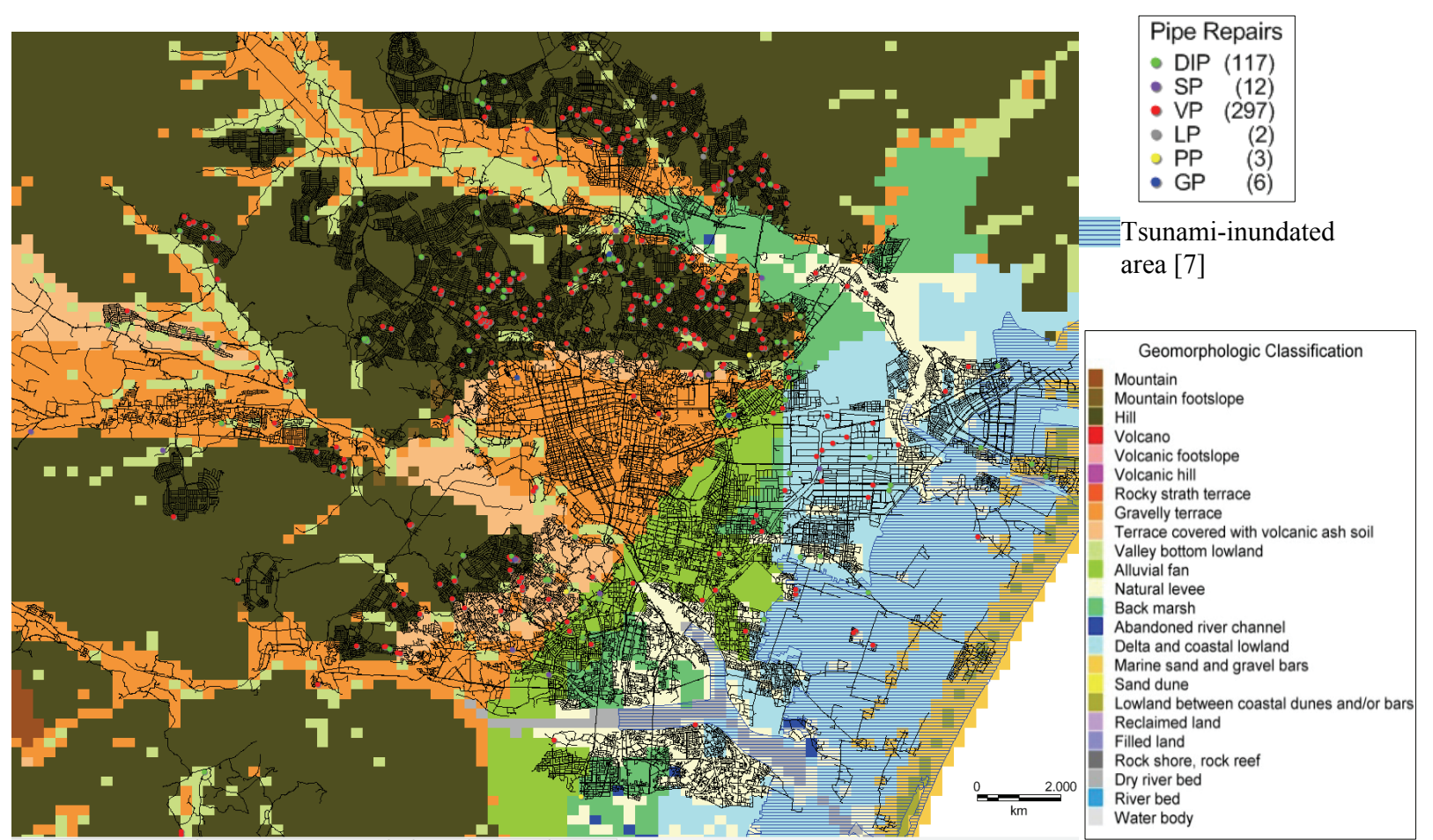

Fig. 4 Locations of pipe repairs and the water distribution network (black lines) superimposed on the 7.5-sec Japan Engineering Geomorphologic Classification Map [20].

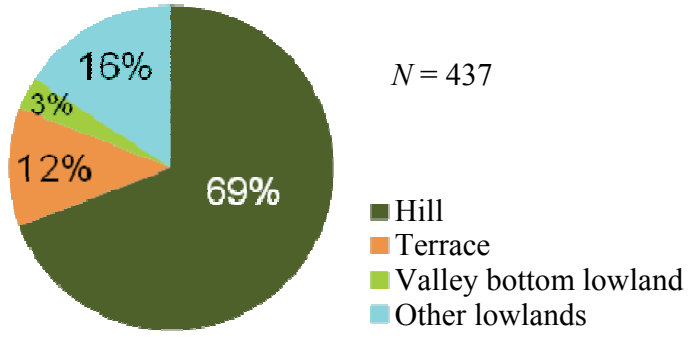

Fig. 5 Percentage of pipe repairs according to geomorphologic land classification.

\section{Effects of the Landform to Pipe Damage}

\subsection{Methodology of Landform Interpretation}

In this study, we examined whether changes in landforms had occurred at 437 locations of water transmission and distribution pipe repair by comparing the present topographic maps [21] and 5-m DEM (grid digital elevation model) [22] with old maps drawn before land development had begun. The old maps include $1: 25,000$ and 1:3,000 scale topographic maps surveyed in 1928 and 1964. The surface elevation prior to land development was examined by reading the old topographic maps. In general, the leveling accuracy for the old topographic maps is an approximately one third contour interval, that is, roughly $\pm 3.3 \mathrm{~m}$ and $\pm 70 \mathrm{~cm}$, respectively. That for $5-\mathrm{m}$ DEM is $\pm 15 \mathrm{~cm}$ [22].

\subsection{Effects of the Artificial Landform Change}

Fig. 6(a) shows the locations of pipe repairs and pipelines superimposed on an old topographic map surveyed in 1964, before development. It should be noted that the hill area is dissected by many small valleys and streams.

The land development of the hilly land in Sendai started in the early 1950s, and gradually extended toward the areas surrounding the old urban district. Fig. 6(b) shows locations of pipe repairs superimposed on the topographic map after the land was developed for residential purposes. The area was typically developed by cutting and leveling the hill and then filling the valleys with soil from the excavated areas of the hills. Therefore, there are two general types of subsurface conditions in the hilly land 


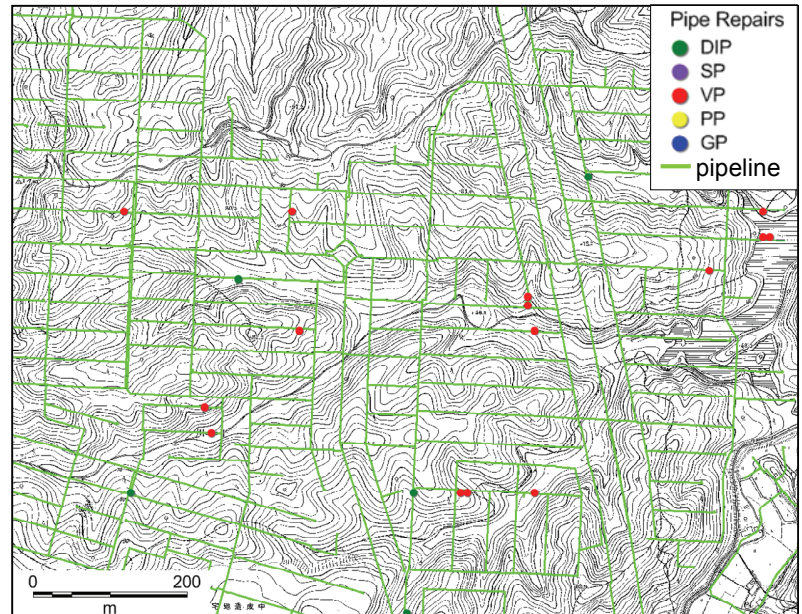

(a)

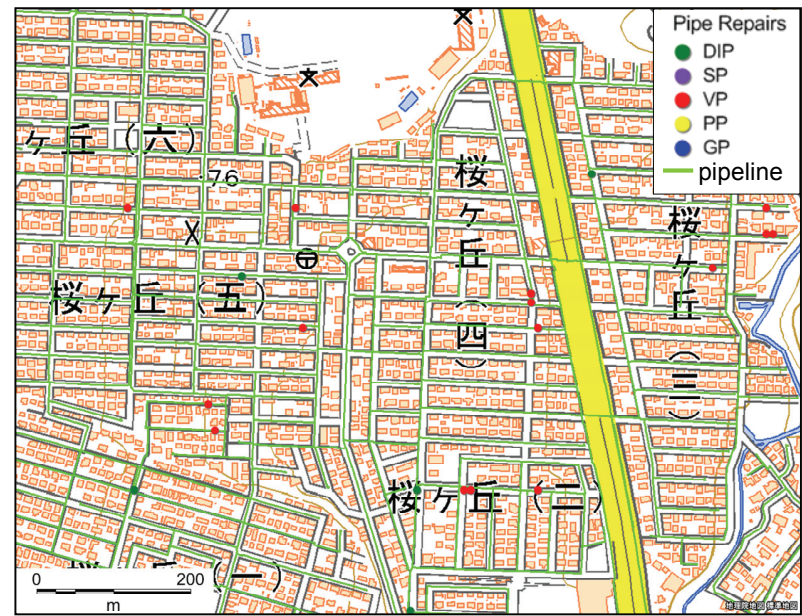

(b)

Fig. 6 Locations of pipe repairs and pipeline network in Sakuragaoka superimposed on topographic maps: (a) topographic map of 1:3,000 scale surveyed in 1964 (before development); (b) topographic map at present.

of Sendai: (1) natural soils of the original or excavated surface of the hill, which are associated with the volcanic pumice flow deposit overlying Neocene sedimentary or volcanic bedrocks; (2) fills consisting mainly of the volcanic pumice flow deposited on the valleys in the hill. Areas underlain by these different profiles might behave differently during the earthquakes.

The pie chart in Fig. 7 shows the percentages of landform change at the locations of the 437 pipe repairs, indicating that $78 \%$ of the pipe repairs took place in pipelines installed in the developed areas where landform change was made by cutting and filling. The bar chart in Fig. 8 shows the repair rate of water transmission and distribution pipelines of different geomorphological categories, including percentages of artificial landform change within each category. Nearly all the pipe repair locations in the hill area had undergone landform changes, and the repair rate was more than 3.6 times that of other lowland area without landform change. Two third of the pipe repair locations in the terrace area also had landform changes.

\subsection{Effects of Fill Thickness}

Subsurface ground conditions in the developed areas of hilly land were primarily determined by assessing whether the land was developed by filling a relatively low area such as a valley, or by cutting and leveling a relatively high area such as a hill ridge. Therefore, the thickness of the cutting and filling at a total of 339 locations of pipe repairs was investigated in the developed area. The surface elevation before and

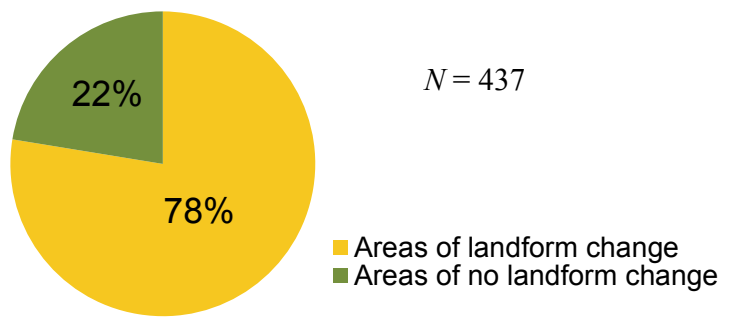

Fig. 7 Percentages of landform change at the locations of water transmission and distribution pipeline repairs.

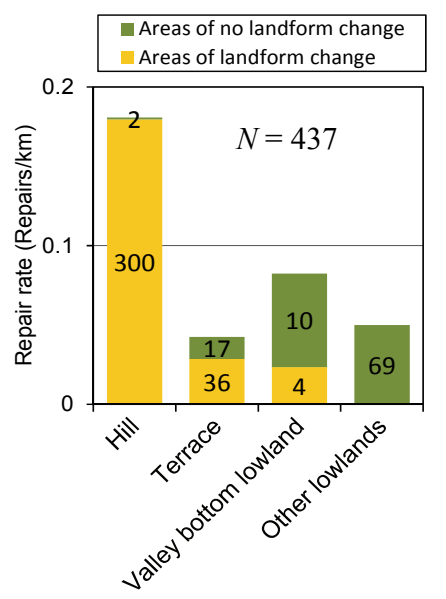

Fig. 8 Repair rate for water distribution network for different geomorphological units to differentiated whether landform change had done or not (number on the bar graph shows the number of pipe repairs). 
after land development was evaluated in the method previously described. The locations where current elevation was higher than before land development were considered to be fill areas in the hill, whereas the locations where elevation was lower than before land development were considered to be cut areas. Thus, the thicknesses of the fillings and cuttings were estimated based on the differences between surface elevations before and after development.

Fig. 9(a) shows the relationship between the thickness of the cut and fill, the number of pipe repairs of VP, and the different pipe diameters, in which negative values represent thicknesses of cutting and positive values represent those of filling. It can be seen from Fig. 9(a) that the heaviest concentration of damage was observed within the boundary area between cutting and filling, with a thickness ranging from $-2.5 \mathrm{~m}$ to $2.5 \mathrm{~m}$. Damage to pipelines, in general, was observed in many fill areas, but was less common in cut areas, regardless of pipe diameter.

Fig. 9(b) depicts the relationship between the thickness of the cut and fill, the number of pipe repairs of DIP, and the different pipe diameters, showing that the heaviest concentration of damage was also found within the boundary area between

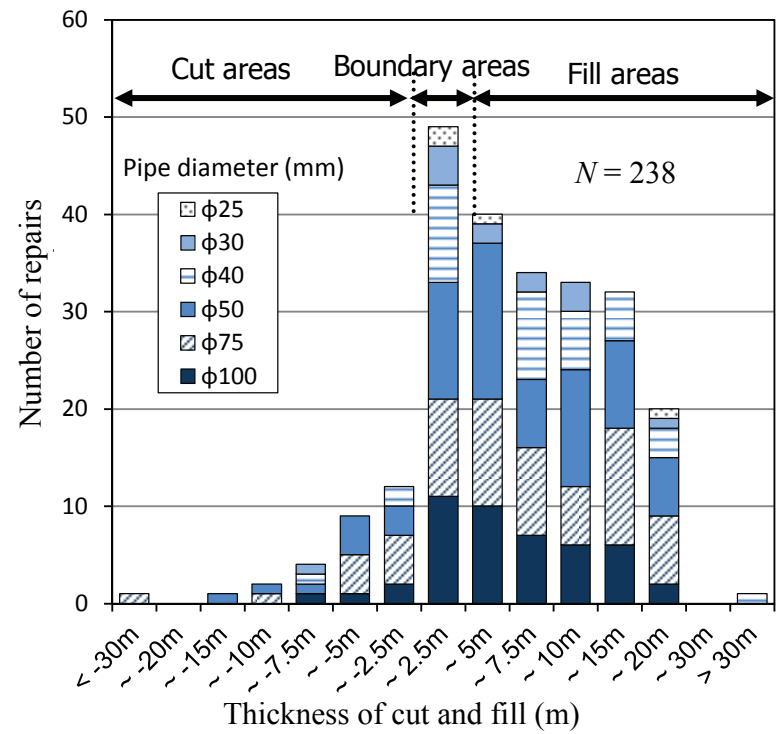

(a) cutting and filling. Larger pipes with diameters exceeding $200 \mathrm{~mm}$ required repairs only within the boundary area and fill areas having a thickness of $10 \mathrm{~m}$ or less.

Figs. 9(a) and 9(b) imply that the performance of the fills placed on the natural ground of hilly areas is directly related to the pipeline damage.

\subsection{Effects of Ground Failures to Pipe Damage}

Significant ground failures occurred in many places in the developed areas of hilly land in Sendai. Ground failures include landslides, slope failures and collapsing of retaining walls (Fig. 10). A lot of pipes damaged due to ground failures reached 5,080 [23]. However, many repairs in the entire area of Sendai, approximately $78 \%$ of the total 437 repairs, occurred outside of the area where severe ground failures took place. Figs. 11(a) and 11(b) show the relationship between the thickness of the cut and fill in the hilly land, the areas affected by ground failures [24], and the number of pipe repairs of VP and DIP, respectively. A number of repairs occurred outside of the areas where the severe ground failures occurred, although most of the ground failures were found to occur in fill areas.

In contrast, no significant liquefaction induced

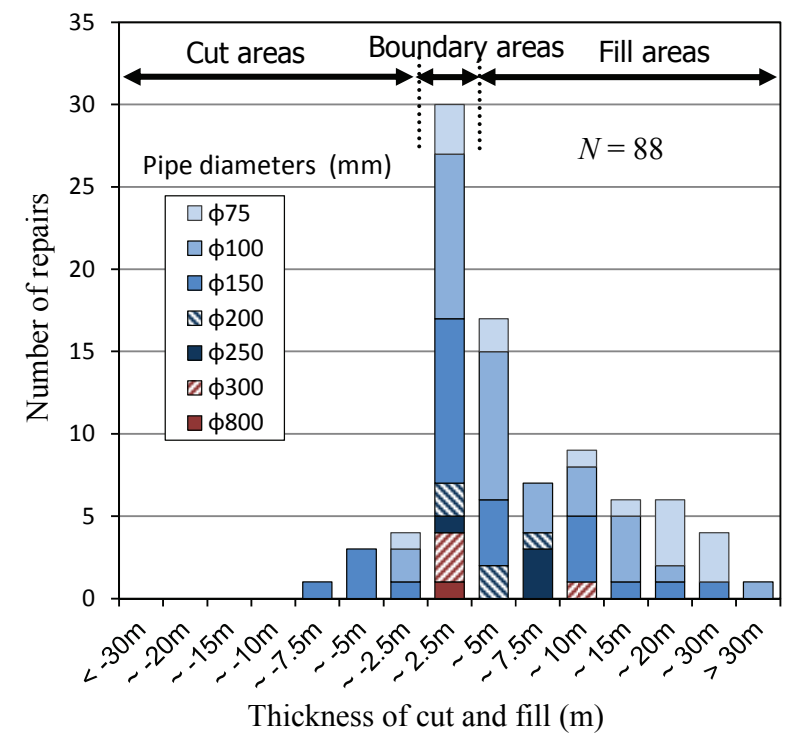

(b)

Fig. 9 Relationship between thickness of the cut/fill and number of pipe repairs, for different pipe diameters: (a) VP; (b) DIP. 


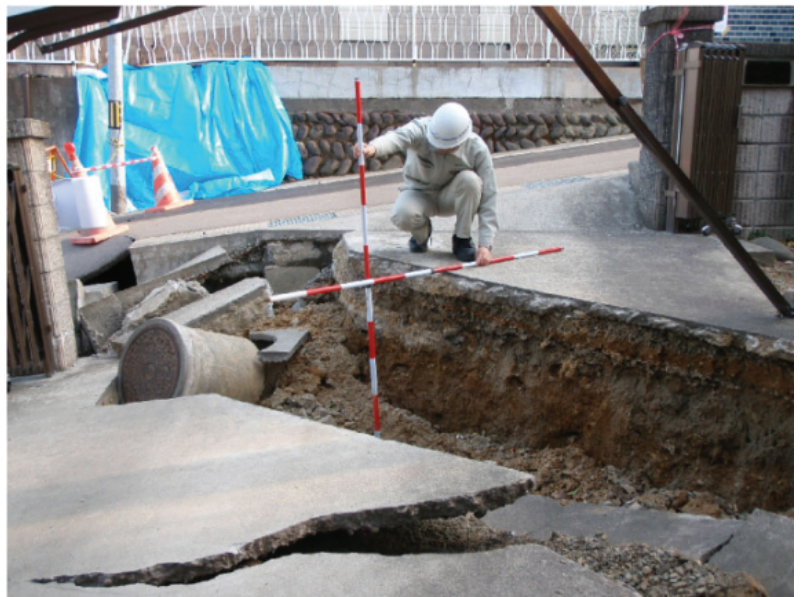

Fig. 10 Large crack due to landslide in Midorigaoka, where a $100 \mathrm{~mm}$-diameter DIP was broken (courtesy of Sendai City).

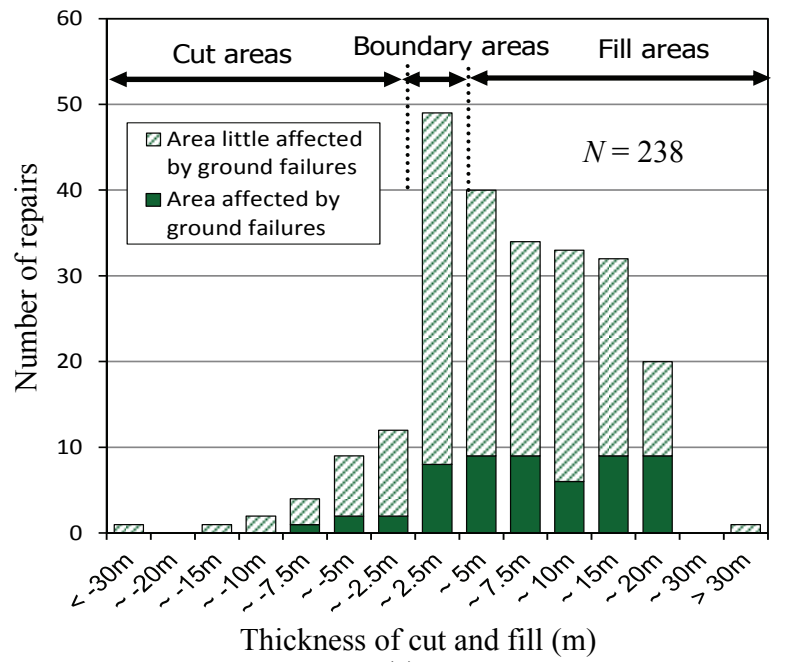

(a)

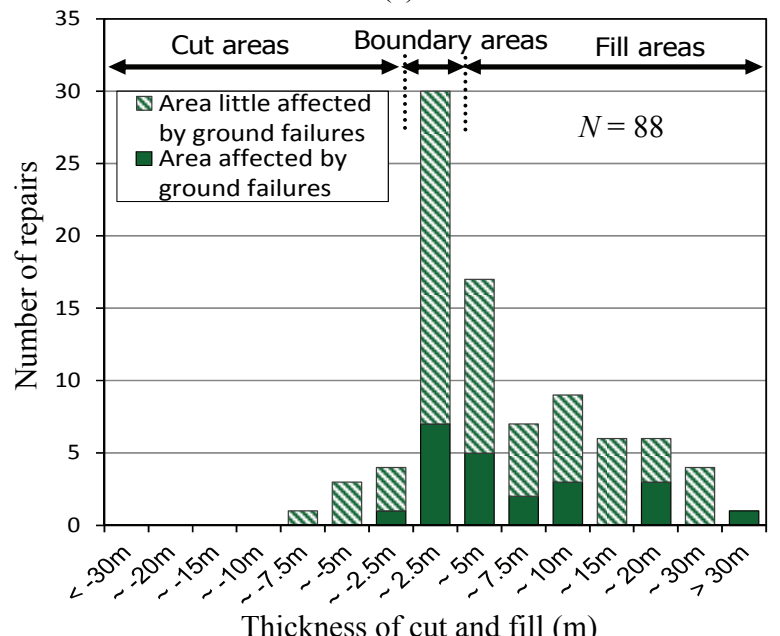

(b)

Fig. 11 Relationship between the thickness of the cut/fill and number of pipe repairs, for areas affected or not by ground failures: (a) VP; (b) DIP. ground failures were observed in the city. Superimposing the locations of pipeline repairs on liquefaction grid cells of approximately $250 \mathrm{~m}^{2}$ containing any site of liquefaction [18], only $7 \%$ of the 437 pipe repairs were within the liquefaction grid cells.

\section{Possible Mechanism of Pipe Damage Outside of the Major Ground Failure Area}

Fig. 12 shows an example of a pipe repair location where no severe ground failure was observed. The current surface elevation is around $40 \mathrm{~m}$ above sea level, and the thickness of the fill was estimated to be more than $10 \mathrm{~m}$. A VP having a diameter of $75 \mathrm{~mm}$ was repaired here. The ground surface displayed a gentle slope and wavy deformation after the earthquake, as shown in the Fig. 12. The pattern of ground deformation suggests that a small amount of lateral spreading of the fill took place from the valley head to land downstream, as shown in Figs. 13(a) and 13(b).

Fig. 14 illustrates a cross section of the pipe repair site shown in Fig. 12, depicting the ground surfaces both before and after land development. It can be seen that the pipe repair occurred in the fill area near the boundary between cutting and filling, where the original landform before development was the slope of a V-shaped valley. This indicates that the pipeline crossing the margin of a lateral spread/slide is subjected to a bending force caused by the moving soil mass, and results in fracture as shown in Fig. 13(b).

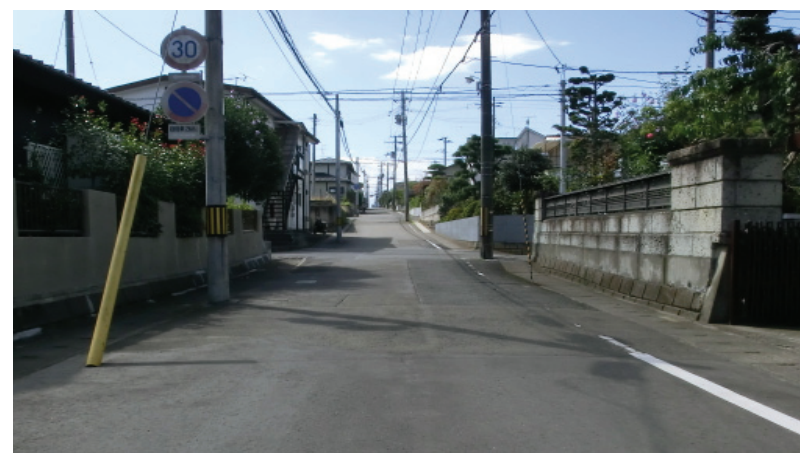

Fig. 12 Pipe repair location where no severe ground failure was reported (Nankoudai 4-chome). 


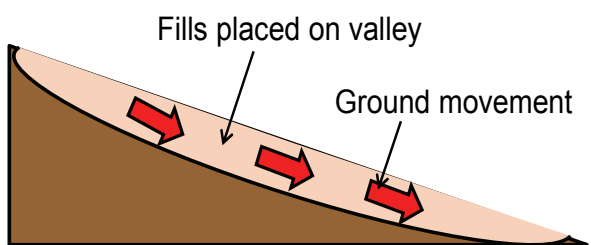

(a)

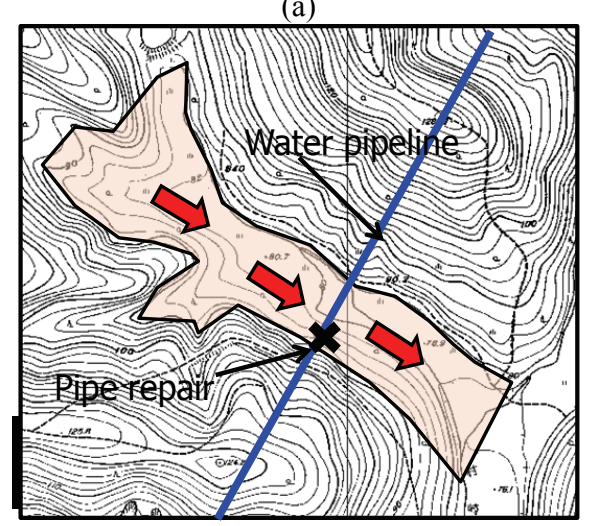

(b)

Fig. 13 Schematics of a typical pipe damage mechanism for an area free of ground failure: (a) cross-sectional view; (b) plane view.

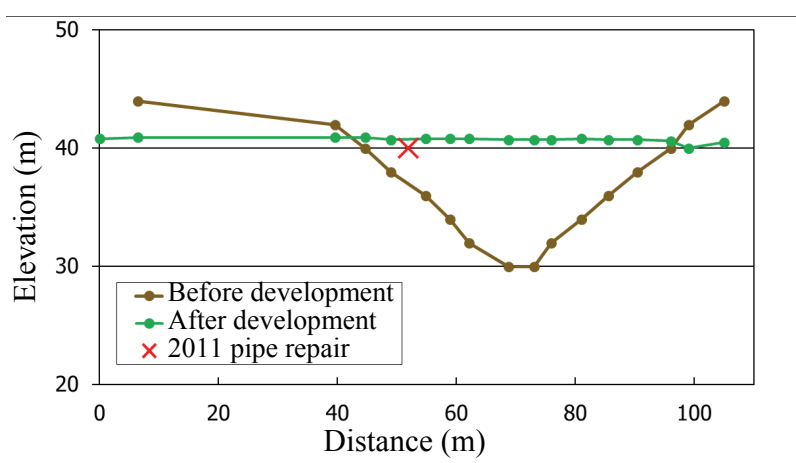

Fig. 14 Cross-section along the pipeline across a valley in Nankoudai 4-chome.

\section{Conclusions}

This study investigated damage to water transmission and distribution pipelines in Sendai City caused by the 2011 Tohoku Earthquake, specifically with respect to landform changes in developed areas of hilly land. The principal findings include:

(1) More than $80 \%$ of the 437 pipe repairs occurred in pipelines installed on hill and terrace areas consisting of hard soil;

(2) Nearly all the pipe repair locations in hilly land are areas of landform change associated with land development for residential purposes over the past several decades. This repair rate was more than 3.6 times that of other lowlands having no landform change;

(3) Concerning thicknesses of cuttings and fillings in developed land, the heaviest concentration of pipe repairs was observed within the boundary areas between cuttings and fillings between thicknesses of $-2.5 \mathrm{~m}$ and $2.5 \mathrm{~m}$. The second heaviest concentration occurred in fill areas, regardless of pipe material;

(4) Many repairs, approximately $78 \%$ of the total 437 repairs, occurred outside of the area where severe ground failures took place;

(5) A small amount of lateral spreading of the fill, assumed to move soil mass from the valley head in the downstream direction, resulted in breaking the pipeline at the margin of the lateral spread/slide, that is, the boundary between cutting and filling.

\section{Acknowledgments}

The authors wish to thank Mr. Masao Nishino and Seiichi Suzuki of Bureau of Waterworks of Sendai, who provided the damage database of Sendai water supply network associated with the 2011 Tohoku Earthquake.

\section{References}

[1] O'Rourke, T. D., Beaujon, P. A., and Schowthon, C. R. 1992. Large Ground Deformations and Their Effects on Lifeline Facilities: 1906 San Francisco Earthquake. Technical report 2, NCEER-92-0002: 3.1-3.85.

[2] Katayam, T., Masui, Y., Isoyama, R., and Jinnai, I. 1979. "Effect of the Miyagiken-Oki Earthquake of June 12, 1978 on Water Supply Systems (Part 1)." Seisan Kenkyu 31 (April): 213-9. (in Japanese)

[3] O'Rourke, T. D., Roth, B. L., and Hamada, M. 1992. Large Ground Deformations and Their Effects on Lifeline Facilities: 1979 San Fernando Earthquake. Technical report 2, NCEER-92-0002: 1.1-1.130.

[4] O'Rourke, T. D., Gowdy, T. E, Stewart, H. E., and Pease, J. W. 1995. "Lifeline Performance and Ground Deformation in the Marina during 1989 Loma Prieta Earthquake." In Proceedings of the 3rd Japan-US Workshop on Earthquake Resistant Design of Lifeline Facilities and Countermeasures against Soil Liquefaction, 129-46.

[5] Wakamatsu, K., Yoshida, N., Suzuki, N., and Tazoh, T. 1992. Liquefaction-Induced Large Ground Deformations and Their Effects on Lifelines during the 1990 Luzon, 
Philippine Earthquake. Technical report 1, NCEER-92-0001: 5.1-5.52.

[6] Joint Reconnaissance Team of Architectural Institute of Japan, Japan Society of Civil Engineers, and the Japanese Geotechnical Society. 2001. Damage to Lifelines. Report on the damage investigation of the 1999 Kocaeli Earthquake in Turkey, 8.1-8.7.

[7] O'Rourke, T. D., Toprak, S., and Sano, Y. 1996. "Los Angeles Water Pipeline System Response to the 1994 Northridge Earthquake." In Proceeding of the 6th Japan-US Workshop on Earthquake Resistant Design of Lifeline Facilities and Countermeasures against Soil Liquefaction, 1-16.

[8] Shirozu, T., Yune, S., Isoyama, R., and Iwamoto, T. 1996. "Report on Damage to Water Distribution Pipes Caused by the 1995 Hyogoken-Nanbu (Kobe) Earthquake." In Proceeding of the 6th Japan-US Workshop on Earthquake Resistant Design of Lifeline Facilities and Countermeasures against Soil Liquefaction Disaster Prevention for Lifeline System, 93-110.

[9] Shih, B. J., Chen, W. W., Wang, P. H., Chen, Y. C., and Liu, S. Y. 2000. "Water System and Natural Gas Pipeline Damages in the Ji-Ji Earthquake - Calculating Repair Rates." In Proceedings of Taiwan-Japan Workshop on Lifeline Performance and Disaster Mitigation during Recent Big Earthquakes in Taiwan and Japan, 63-72.

[10] Earthquake Investigation Committee of the Technical Council on Lifeline Earthquake Engineering, ASCE (American Society of Civil Engineers). 2013. "Water and Wastewater System." In Chile Earthquake of 2010: Lifeline Performance, edited by Tang, A. K., and Eidinger, J. M. Virginia: ASCE.

[11] Knight, S., Giovinazzi, S., and Liu, M. 2012. "Impact and Recovery of the Kaiapoi Water Supply Network Following the September 4th, 2010 Darfield Earthquake, New Zealand." In Proceedings of the 15th World Conference on Earthquake Engineering, 1-10.

[12] O'Rourke, T. D., Jeon, S. S., Toprak, S., Cubrinovsk, M., Hughes, M., and Van Ballegooy, M., et al. 2014. "Earthquake Response of Underground Pipeline Networks in Christchurch, New Zealand." Earthquake Spectra 30 (1): 183-204.

[13] Sendai City. 2012. "Data Sendai." Sendai City. Accessed October 19, 2012. http://www.city.sendai.jp/kikaku/seisa $\mathrm{ku} /$ yoran/data_sendai/index.html. (in Japanese)

[14] NIED (National Research Institute for Earth Science and Disaster Prevention). 2011. "Strong-Motion Seismograph
Network (K-NET).” NIED. Accessed January 26, 2014. http://www.kyoshin.bosai.go.jp.

[15] Tohoku Institute of Technology. 2011. "Strong-Motion Records Obtained by Small-Titan of Tohoku Institute of Technology during the 2011 Great East Japan Earthquake.” Tohoku Institute of Technology. Accessed January 26, 2014. http://smweb.tohtech.ac.jp/smalltitan/e nglish/index.html.

[16] Bureau of Waterworks of Sendai City. 2012. "Restoration Record on Water Service in Sendai City Associated with the Great East Japan Earthquake.” Bureau of Waterworks of Sendai City. Accessed January 23, 2013. http://www.suidou.city.sendai.jp/06_bousai/jisin7.html. (in Japanese)

[17] Geospatial Information Authority of Japan. 2011. "Tsunami Inundated Maps with a Scale of 1 to 25,000 during the 2011 off the Pacific Coast of Tohoku Earthquake." Geospatial Information Authority of Japan. Accessed July 28, 2011. http://www.gsi.go.jp/kikaku/kikaku40014.html.

[18] Wakamatsu, K., and Senna, S. 2015. "650-km Long Zone of Liquefaction during the 2011 off the Pacific Coast of Tohoku, Japan Earthquake." In Proceedings of 6th International Conference on Earthquake Geotechnical Engineering, 1-9.

[19] Matsuoka, M., Wakamatsu, K., Hashimoto, M., Senna, S., and Midorikawa, S. 2015. "Evaluation of Liquefaction Potential for Large Areas Based on Geomorphologic Classification.” Earthquake Spectra 31 (4): 2375-95.

[20] Wakamatsu, K., and Matsuoka, M. 2013. "Nationwide 7.5-Arc-Second Japan Engineering Geomorphologic Classification Map and Vs30 Zoning." Journal of Disaster Research 8 (5): 904-11.

[21] Geospatial Information Authority of Japan. "GSI Maps." Geospatial Information Authority of Japan. Accessed July 31, 2015. http://maps.gsi.go.jp/.

[22] Geospatial Information Authority of Japan. 2011. "5-m Grid Digital Elevation Model." Geospatial Information Authority of Japan. Accessed May 18, 2012. http://fgd.gsi.go.jp/download/.

[23] Sendai City. 2012. "Map of Damaged Housing Lots." Sendai City. Accessed July 31, 2013. http://www.city.sen dai.jp/jutaku/takuchihisai_010.html. (in Japanese)

[24] Sendai City. 2013. "Current State of District Examined for Public Work Project." Sendai City. Accessed July 15, 2013. http://www.city.sendai.jp/jutaku/takuchihisai_020. html. (in Japanese) 